continue delivery of journals to interested institutions. Initial efforts to contact the 25 departments and libraries receiving Association publications has let to positive responses from libraries in Zimbabwe, Senegal, Kenya, and Ethiopia who are interested in continued shipment. The Association hopes to be in contact with a number of the other institutions in the near future.

\section{Travel Grants for 1997 Annual Meeting}

The Association will again offer a limited number of travel grants for graduate students to attend the 1997 Annual Meeting in Washington, DC. Funded through the generosity of APSA members, the maximum award for any grant will be $\$ 300$. Grant will be awarded in two categories: (1) Foreign graduate students attending US institutions and (2) Advanced American graduate students.

Applicants must complete a short application available from the APSA National Office and are required to have a letter of support prepared by their department chair. Applicants without a letter of support will not be considered.

The deadline for recipient of the complete application is July 5. Application forms and further information are available by contacting Sean Twombly at twombly@aspanet.org.

\section{APSA Surveys Political Scientists about Job Placement}

The National Science Foundation is funding a collaborative effort with APSA to collect information about job placement among newly-minted Ph.D.s and ABDs in political science. This project involves the placement class of 1995-96 and is designed to provide insight into how graduate departments and APSA can better inform and assist political scientists in their search for jobs. Surveys were mailed out in the fall of 1996 .

Once the data is gathered and an- alyzed, APSA is planning to publish the findings in $P S$ and conduct a session on placement at the 1998 Annual Meeting in Boston.

In addition to funding the survey for political science, NSF has collaborated with the professional associations of chemistry, geology, mathematics, computer science, and psychology to gather information on placement. Next year, NSF plans to include new Ph.D.s and ABDs in economics, sociology, engineering, and microbiology.

\section{Maynes Assumes Presidency of the Eurasia Foundation}

Charles William Maynes, Editor of Foreign Policy and former APSA Congressional Fellow, was recently named President of the Eurasia Foundation. Maynes replaces Ambassador Thomas Pickering who has been nominated to the position of Undersecretary of State for Political Affairs.

In the course of his career, Maynes has held a number of posts in both the public and private sector. A graduate of Harvard College and a Rhodes Scholar at Oxford University, he entered the Foreign Service in 1962, where he had successive assignments in UN Political Affairs, the US Aid Mission in Laos, and the Economic Section in the American Embassy in Moscow.

In 1970 Maynes was awarded a Congressional Fellowship by the ASPA and worked for Congressman F. Bradford Morse (R-MA) and Senator Fred R. Harris, (D-OK). In

\section{Correction:}

The following dissertation listing is a corrected version of the one published in the December issue of PS:

Miriam Fendius Elman: B.A., Hebrew University, 1988; M.Phil, Columbia, 1993; Ph.D., Ibid., 1996. When the Weak Go to War: Domestic Institutional Choices and Their Foreign Policy Legacies. Columbia.
1972 he became head of the New York Office of the Carnegie Endowment for International Peace and in 1974 became its secretary, the second highest position in the Institution. After an appointment by President Carter as Assistant Secretary for International Organization Affairs in 1977 he assumed editorship of Foreign Policy in 1980.

Established in 1993 with a major grant from USAID to promote democracy and free markets in the New Independent States of the former Soviet Union, the Eurasia Foundation maintains its offices in the APSA building.

\section{Ralph Bunche Institute Participants Selected}

Fifteen outstanding African American students have been selected to participate in the 11th Ralph Bunche Summer Institute. The 1997 Institute will be held on the historic grounds of the University of Virginia on June 8-July 10, 1997. The Institute is designed to introduce promising African American students to the world of graduate study and encourage application to $\mathrm{Ph} . \mathrm{D}$. programs.

The Institute includes two transferable credit courses: quantitative analysis and race and American politics. In addition, guest lecturers and recruiters from Ph.D. programs, as well as the Educational Testing Service, visit with students. The academic environment is challenging, yet supportive. Students learn skills to be successful in as graduate scholars. Most students who attend the Ralph Bunche Summer Institte excel in their senior year and go on to graduate school, many with full graduate fellowships and teaching assistantships.

1997 participants include:

Jhamed Babatunde-Bey, UCLA Tashna Brightwell, Xavier University Kenita Brown, Xavier University Khalilah Brown, University of Virginia Duane Crooks, University of Miami LaKisha Fields, University of South Carolina Fatima Goss, UCLA Maria Kirby, Harvard University Tiffany Miller, Kent State University Dana Olds, Lincoln University Michael Salmon, University of Miami 


\section{U.S. Said to Spend More on Jails Than on Colleges}

Americans are spending more money on prisons than on colleges, according to a report released last month by the Justice Policy Institute, a research and advocacy organization in Washington.

The analysis of state and federal budgets shows that, from 1987 to 1995 , spending on prisons increased by $30 \%$ while spending on higher education fell by $18 \%$.

The report's authors say that the enactment of stiffer criminal sentences nationwide has come at a cost to higher education.

They say that America's war on drugs has sent a skyrocketing number of non-violent offenders to jail, and that over the past two decades, police spending has increased fivefold, even though "the fear of victimization is unsubstantiated by the statistics." Over the last two decades, they say, crime rates in most categories have remained relatively stable, while illiteracy and unemployment rates have climbed.

\section{According to the report:}

- From 1990 to 1994 , only 7 states increased higher-education spending as a proportion of their state budgets, but 36 states increased the share of spending devoted to corrections programs.

- In 1995 , spending by states on prison construction increased by \$926-million, while building funds for higher education dropped by almost the same amount.

To obtain a copy of the report, write to the Justice Policy Institute, 2208 Martin Luther King Jr. Avenue, S.E., Washington 20020 , or call (202) 678-9282.

Reprinted with permission from the Chronicle of Higher Education.
Travis Simmons, North Carolina

A\&T University

Byron Thomas, Hampton University

Vincent Ward, University of $\mathrm{N}$ Mexico

Demecher Ware, Mississippi Valley State University

The Institute has been generously funded by the National Science Foundation, the Ford Foundation, the Coca-Cola Foundation, the U.S. Department of Education, Emory University, University of Virginia, The William S. Paley Foundation, the Georgia State University Foundation, and members of the APSA.

For more information, please contact: the Ralph Bunche Summer Institute, APSA, 1527 New Hampshire Avenue NW, Washington, D.C. 20036 or via e-mail:

bunche@apsanet.org.

\section{APSA Announces a New Spring Round for the Minority ID Project}

In response to suggestions from participating graduate schools, a new "Spring Round" has been added to the APSA's Minority Identification Project. The MID Spring Round is designed to allow graduate schools, many of which have application deadlines in early December, ample time to utilize the list of minority candidates provided to them.

The Minority ID Project was created to increase the representation of minorities in the political science profession. Under the MID, faculty select minority students within their department who demonstrate the aptitude to succeed in graduate programs in political science. ASPA then generates a list of these minority students and sends the list to over 30 participating graduate programs. Graduate programs use this information to recruit minority students.

For more information on the MID, contact Jun Yin at jyin@apsanet.org or Polly Leonard at pleonard@apsanet.org or by telephone at (202) 483-2512.

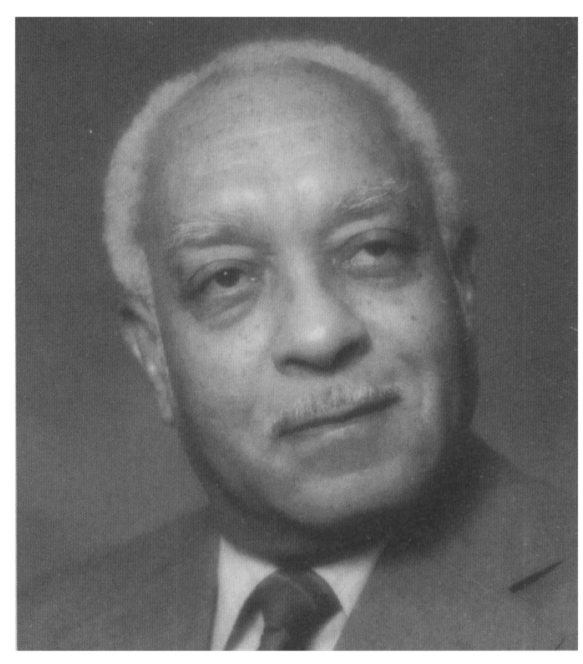

Rudolph Gordon

\section{Rudolph Gordon \\ Recognized for Distinguished Service}

Rudolph Gordon, dean emeritus, Norfolk State University was honored with a Distinguished Service Award from the APSA Committee on the Status of Blacks in the Profession. The award was presented in recognition of his career of scholarship, teaching, and service to the profession. The committee also recognized San Francisco Mayor Willie Brown, for his lifetime contributions. stable, while illiteracy and unemployment rates have climbed.

\section{D'Arms Named President of ACLS}

The Board of Directors of the American Council of Learned Societies recently appointed John $\mathrm{H}$. D'Arms as the next President of the ACLS. He will assume the presidency on September 1, 1997.

D'Arms is Gerald F. Else Professor of Humanities, Professor of Classical Studies, and Professor of History at the University of Michigan. A UM faculty member since 1965 , D'Arms served as chairman of his department for nine years, and received the Else named position in 1983. From 1985-95 he was Dean of the Horace F. Rackham School of Graduate Studies.

D'Arms earned his Ph.D. in classi- 